Gut, 1986, 27, 491-498

\title{
Evaluation of the nitrosamine hypothesis of gastric carcinogenesis in precancerous conditions
}

\author{
C N HALL, D DARKIN, R BRIMBLECOMBE, A J COOK, J S KIRKHAM, AND \\ T C NORTHFIELD
}

From the Norman Tanner Gastroenterology Unit, St. James' Hospital, Balham, London; Public Health Laboratories, Porton Down; and Smith Kline Research Ltd, Welwyn Garden City, Herts.

SUMmaRY A 24 hour gastric aspiration study was carried out on nine Polya gastrectomy, eight pernicious anaemia, and nine matched control subjects. Intragastric $\mathrm{pH}$, bacteria, nitrite, and $\mathrm{N}$ nitroso compounds were assessed half hourly whilst ambulant and hourly when in bed. Both total and nitrate reducing bacterial counts were positively related to $\mathrm{pH}\left(\chi^{2}=279 \cdot 3 ; \mathrm{p}<0 \cdot 001\right)$, as was nitrite concentration $(\mathrm{F}=19.1 ; \mathrm{p}<0.0001)$. By contrast, total $(\mathrm{F}=40.6 ; \mathrm{p}<0.0001)$ and stable $(\mathrm{F}=257.4 ; \mathrm{p}<0.0001) \mathrm{N}$-nitroso compound concentrations were negatively related to $\mathrm{pH}$. Clear differences in these gastric juice factors were not apparent between matched control and either pernicious anaemia, or Polya gastrectomy because the Polya gastrectomy and matched control groups were heterogeneous for gastric acidity. Thus, although eight of eight pernicious anaemia subjects were hypoacidic (defined as intragastric $\mathrm{pH}>4$ for $>50 \%$ of both daytime and night time periods), only five of nine Polya gastrectomy and two of nine matched control subjects were hypoacidic. When subjects were rearranged into hypoacidic $(n=15)$ and acidic $(n=11)$ groups, bacterial counts $(p<0.01)$ and nitrite concentrations $(p<0.01)$ were higher, whereas $N$ nitroso compounds tended to be lower (NS) in the hypoacidic group. These data suggest that, although hypoacidity predisposes to bacterial overgrowth and nitrite generation, it does not enhance nitrosation. Instead, this is maximal at low $\mathrm{pH}$, suggesting chemical rather than bacterial nitrosation, contrary to the nitrosamine hypothesis of gastric carcinogenesis.

The incidence of hypochlorhydria has been reported to be as high as $85-90 \%$ in gastric cancer, ${ }^{12}$ and it has been shown that hypochlorhydria may precede gastric cancer by several years. ${ }^{3}$ The hypochlorhydric states of Polya gastrectomy ${ }^{4-6}$ (15 years after surgery) and pernicious anaemia ${ }^{78}$ are accompanied by an increased incidence of gastric cancer, and are considered to be precancerous conditions. ${ }^{9}$ The nitrosamine hypothesis of gastric carcinogenesis postulates that high intragastric $\mathrm{pH}$ in hypochlorhydria promotes the growth of bacteria which reduce dietary nitrate to nitrite and then convert dietary amines, in the presence of this nitrite, into $\mathrm{N}$-nitroso compounds. ${ }^{1011} \mathrm{~N}$-nitroso compounds are proven carcinogens in all mammalian species tested, ${ }^{12}$ and may initiate cellular mutations of increasing serverity in the human stomach eventually culminating in cancer.

Address for correspondence: Dr T C Northfield. Department of Medicine II. St George's Hospital. Cranmer Hospital, London SW17 ORE.

Received for publication 28 August 1985.
In vitro, the rate of $\mathrm{N}$-nitroso compound synthesis by simple chemical reaction between precursors is maximal at low $\mathrm{pH}(\mathrm{pH}<4) .{ }^{13}$ Some early studies $^{14-16}$ suggested that certain bacteria may catalyse nitrosation enzymatically at neutral $\mathrm{pH}$ but much of these data are now disputed, ${ }^{17}$ and it appears that the observed nitrosation may have occurred chemically in the complex culture media used. Bacteria do, however, appear capable of enhancing chemical nitrosation in vitro by lowering the $\mathrm{pH}$ of the culture medium and by generating nitrite. Even so, as bacteria are incapable of generating or surviving at the low $\mathrm{pH}$ optimal for chemical nitrosation, these enhancing effects may be insignificant. In vivo, the relative rates of chemical nitrosation at acid $\mathrm{pH}$ and bacterial nitrosation at neutral $\mathrm{pH}$ will determine whether $\mathrm{N}$-nitroso compound concentrations are higher in the gastric juice of normal or of hypochlorhydric subjects.

In order to test the nitrosamine hypothesis of gastric carcinogenesis, we have studied nine Polya gastrectomy, eight pernicious anaemia and nine 
matched control subjects. We obtained gastric juice over a 24 hour period designed to simulate the activities of normal daily life, and measured bacteria (total and nitrate reducing), nitrite and $\mathrm{N}$-nitroso compounds (total and stable). We compared the measurements in the different groups and also related them to intragastric $\mathrm{pH}$, to ascertain whether bacterial counts, nitrite and $\mathrm{N}$-nitroso compound concentrations are all highest at high $\mathrm{pH}$, as predicted by the nitrosamine hypothesis.

\section{Methods}

\section{SUBJECTS}

Nine Polya gastrectomy subjects (Visick I and II) at least 15 years post surgery were compared with nine healthy volunteers free of gastrointestinal disease, and with eight pernicious anaemia subjects diagnosed on the basis of macrocytic anaemia, vitamin $B_{12}$ deficiency and vitamin $B_{12}$ malabsorption correctable by intrinsic factor. They were matched in eight triplets (plus an additional Polya gastrectomymatched control pairing) for race, sex, and age to nearest decade (Table 1). Matching of the groups was also similar for height, but pernicious anaemia tended to be heavier than the other two groups (NS).

\section{EXPERIMENTAL DESIGN}

A size 12 salem sump tube was sited radiologically in the stomach at the start of the study and its position rechecked at the end. This precaution was taken as, in spite of marking the tube and taping it firmly to the nose, there was a tendency in the Polya gastrectomy subjects for the tube to drift into the upper jejunum. Data were only accepted from those studies in which the position of the tube was known to be correct for the full duration of the study period.

Gastric juice was analysed over a 24 hour period designed to simulate normal daily life, and was aspirated half hourly whilst subjects were ambulant (0900-2400 h) and hourly when they were in bed (0100-0800 h). Three standardised solid meals were fed at $0930 \mathrm{~h}, 1330 \mathrm{~h}$, and $1730 \mathrm{~h}$; beverages were given at $1130 \mathrm{~h}, 1530 \mathrm{~h}$ and $2130 \mathrm{~h}$.

Table 1 Matching of patient groups

\begin{tabular}{lccc}
\hline & $\begin{array}{l}\text { Polya } \\
\text { gastrectomy }\end{array}$ & Controls & $\begin{array}{l}\text { Pernicious } \\
\text { anaemia }\end{array}$ \\
\hline Age (yr) & $64 \pm 3$ & $63 \pm 3$ & $66 \pm 3$ \\
Sex (M:F) & $7: 2$ & $7: 2$ & $6: 2$ \\
Height (cm) & $173 \pm 2$ & $170 \pm 4$ & $172 \pm 4$ \\
Weight (kg) & $69 \pm 3$ & $67 \pm 4$ & $76 \pm 5$ \\
Race: all caucasians & & & \\
\hline
\end{tabular}

Intragastric $\mathrm{pH}$ was measured by glass electrode immediately upon the aspiration of gastric juice. In individual subjects hypoacidity was defined as intragastric $\mathrm{pH}>4$ for $>50 \%$ of both daytime and night time periods. Aerobic and anaerobic bacteria were cultured and counted using the methods of Borriello et al. ${ }^{18}$ Total bacterial counts $>10^{5}$ organisms $/ \mathrm{ml}$ were considered pathological ${ }^{19}$ and bacterial overgrowth was diagnosed when all counts from one individual were $>10^{5}$ organisms $/ \mathrm{ml}$.

Nitrite concentrations were estimated by polarography after immediate buffering of gastric juice with borax $(\mathrm{pH}>7)$ and storage at $-10^{\circ} \mathrm{C}$. $\mathrm{N}$-nitroso compound concentrations were measured by the method of Bavin et al. ${ }^{20}$ In brief, hydrazine sulphate was added to samples to destroy nitrite and the mixture adjusted to $\mathrm{pH} 4$. An aliquot was then added to $\mathrm{HBr} /$ acetic acid and the nitrous oxide evolved was measured by chemiluminescence as an estimate of the $\mathrm{N}$-nitroso compounds present. This procedure was done immediately upon the aspiration of gastric juice to assess the total $\mathrm{N}$-nitroso compounds, and was repeated five days later (after storage of treated sample) to measure the stable $\mathrm{N}$ nitroso compounds.

\section{STATISTICS}

Mean values refer to means for individual subjects, and average means to the average values obtained for several individuals within a group. Differences in mean data between subjects in the Polya gastrectomy, pernicious anaemia and matched control groups were tested for significance by the paired Student's $t$ test as the individuals in these groups were matched as shown in Table 1 . The significance of diurnal differences within the Polya gastrectomy, pernicious anaemia, matched control, acidic and hypoacidic groups was also tested by this method as the two time periods were of equal length and each subject acted as his own control. Comparison of data from the acidic and hypoacidic groups was made by the Wilcoxon's rank sum test. The relationship between the percentage of samples having $>10^{5}$ bacteria/ml and intragastric $\mathrm{pH}$ was tested by the $\chi^{2}$ test of the null hypothesis that $\mathrm{pH}$ was not related to bacterial counts. ${ }^{21}$ The relationships between mean concentrations of nitrite, total and stable $\mathrm{N}$-nitroso compounds and intragastric $\mathrm{pH}$ were assessed by a one way analysis of variance using a linear contrast to test for the regression of concentration on $\mathrm{pH}$. The results are expressed as an $\mathrm{F}$ ratio. ${ }^{21}$ To further test $\mathrm{pH}$ relationships, mean values of nitrite and total and stable $\mathrm{N}$-nitroso compounds as well as \% samples having $>10^{5}$ organisms $/ \mathrm{ml}$ were calculated in individual subjects, and the relationship between these factors and mean 
intragastric $\mathrm{pH}$ tested by the Kendall Rank correlation coefficient. The results are expressed as a $\tau$ value.

\section{Results}

Eleven Polya gastrectomy, eight pernicious anaemia and nine matched control subjects took part in this study, but data from two Polya gastrectomy subjects had to be completely discarded because of poor nasogastric tube placement diagnosed radiologically at the end of the study. Numerically, although 1040 samples should have been harvested from the 26 successful studies, in actual fact there was a deficit of 176 samples spread evenly across the groups because on occasion, particularly in the fasting state, the stomach was empty and no gastric juice was aspirated.

\section{pH RELATIONSHIPS}

The effect of $\mathrm{pH}$ on the various gastric juice factors under investigation was assessed by allocating all of the samples $(n=864)$ to different categories of $\mathrm{pH}$, each category encompassing one unit of $\mathrm{pH}$.

\section{BACTERIOLOGY}

The percentage of samples in each $\mathrm{pH}$ category containing more than $10^{5}$ organisms $/ \mathrm{ml}$ was calculated (Fig. 1). The incidence of counts $>10^{5} \mathrm{ml}$ of both total and nitrate-reducing bacteria increased linearly from $\mathrm{pH} 1.15$ to $\mathrm{pH} 3.99 \quad\left(\chi^{2}=279.3\right.$; $\mathrm{p}<0.0001)$. Virtually all samples of $\mathrm{pH} 4.00-7.92$ contained counts of bacteria $>10^{5} / \mathrm{ml}$ suggesting colonisation.

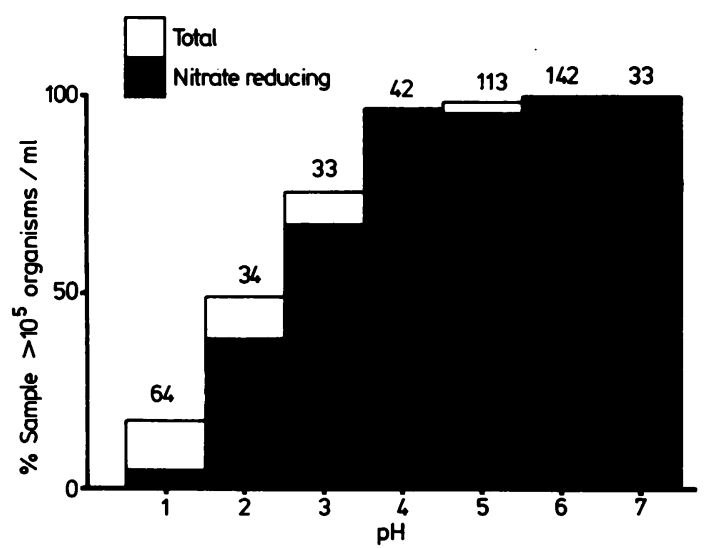

Fig. 1 Relationship between incidence of pathological bacterial counts and intragastric $p H .{ }^{*}$ Number of samples in each $\mathrm{pH}$ category.
NITRITE AND N-NITROSO COMPOUNDS

Mean concentrations of these factors were calculated for each $\mathrm{pH}$ category. Nitrite concentration (Fig. 2) increased with increasing $\mathrm{pH}(\mathrm{F}=19 \cdot 1$; $\mathrm{p}<0.0001)$. There was a small incremental rise in concentration from very low values at $\mathrm{pH} 1.15-1.99$ to $\mathrm{pH} 3 \cdot 00-3.99$. In the $\mathrm{pH}$ range $4.00-7.92$ nitrite concentrations were markedly raised corresponding to the high counts of nitrate reducing bacteria found at these $\mathrm{pH}$ values. The concentration of both total $(F=40.6 ; \quad p>0.0001)$ and stable $(F=257.4$; $\mathrm{p}<0.0001) \mathrm{N}$-nitroso compounds decreased with increasing $\mathrm{pH}$ (Figs 3 and 4). A plateau of high values occurred across the $\mathrm{pH}$ range $1 \cdot 15-3.99$, and much reduced concentrations occurred at $\mathrm{pH}$ $4 \cdot 00-7 \cdot 92$.

GASTRIC JUICE IN INDIVIDUAL SUBJECTS

Within individual subjects the 24 hour gastric juice

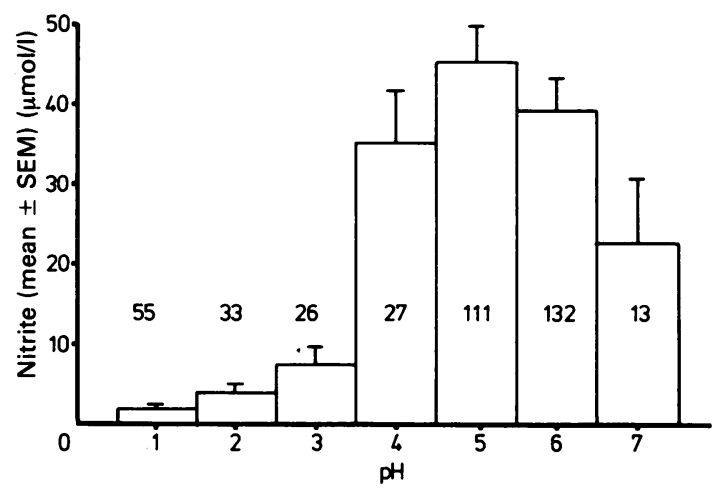

Fig. 2 Relationship between nitrite and intragastric $p H$.

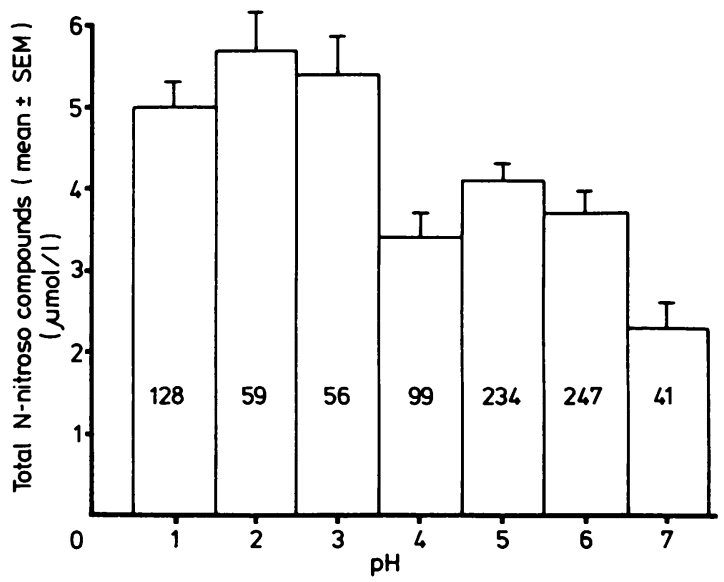

Fig. 3 Relationship between total $N$-nitroso compounds and intragastric $\mathrm{pH}$. 


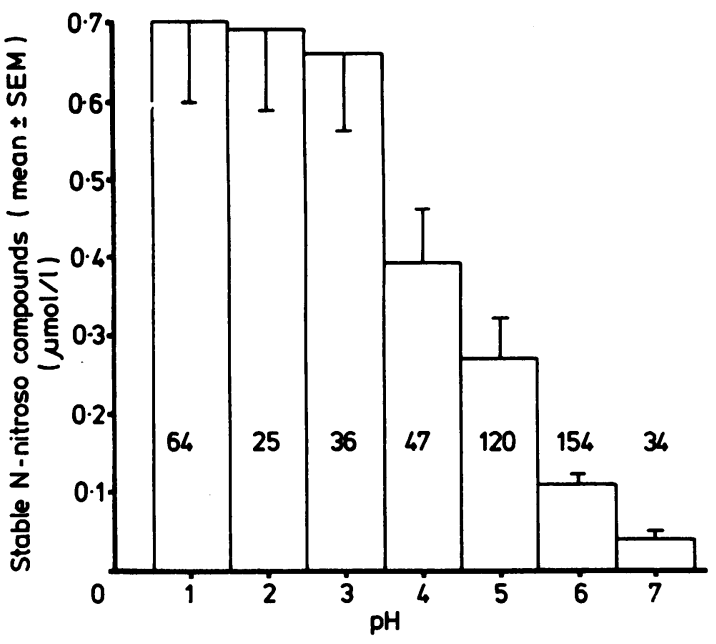

Fig. 4 Relationship between stable $N$-nitroso compounds and intragastric $p H$.

Table 2 Diurnal variations within groups

\begin{tabular}{cllll}
\hline Factor ( \pm SEM) & $\begin{array}{l}\text { Dayl } \\
\text { night }\end{array}$ & $\begin{array}{l}\text { Polya } \\
\text { gastrectomy }\end{array}$ & $\begin{array}{l}\text { Matched } \\
\text { control }\end{array}$ & $\begin{array}{l}\text { Pernicious } \\
\text { anaemia }\end{array}$ \\
\hline pH & $\mathrm{D}$ & $85 \cdot 7 \pm 8$ & $48 \cdot 0 \pm 14$ & 100 \\
(\% samples & & & & \\
> pH 4) & $\mathrm{N}$ & $66 \cdot 8 \pm 12$ & $34 \cdot 8 \pm 11$ & 100 \\
Total bacteria & $\mathrm{D}$ & $92 \cdot 1 \pm 6^{*}$ & $84 \cdot 7 \pm 6^{*}$ & 100 \\
$(\%$ samples & & & & \\
$>10^{5}$ org/ml) & $\mathrm{N}$ & $69 \cdot 1 \pm 13$ & $55 \cdot 2 \pm 14$ & 100 \\
NO $_{3}$ reducers & $\mathrm{D}$ & $83 \cdot 5 \pm 7$ & $76 \cdot 2 \pm 7^{*}$ & 100 \\
$(\%$ samples & & & & \\
$>10^{5}$ org/ml) & $\mathrm{N}$ & $62 \cdot 5 \pm 13$ & $52 \cdot 5 \pm 13$ & 100 \\
Nitrite & $\mathrm{D}$ & $12 \cdot 7 \pm 4$ & $23 \cdot 0 \pm 8$ & $61 \cdot 0 \pm 7$ \\
$(\mu \mathrm{mol} /)$ & $\mathrm{N}$ & $8 \cdot 1 \pm 5$ & $24 \cdot 8 \pm 14$ & $43 \cdot 8 \pm 6$ \\
Total N-nitroso & $\mathrm{D}$ & $4 \cdot 2 \pm 0 \cdot 8$ & $4 \cdot 7 \pm 0 \cdot 5$ & $4 \cdot 1 \pm 0 \cdot 6^{*}$ \\
$(\mu \mathrm{mo} / \mathrm{l})$ & $\mathrm{N}$ & $3 \cdot 3 \pm 0 \cdot 5$ & $3.9 \pm 0 \cdot 9$ & $2 \cdot 7 \pm 0 \cdot 3$ \\
Stable n-nitroso & $\mathrm{D}$ & $0 \cdot 24 \pm 0 \cdot 05$ & $0 \cdot 60 \pm 0 \cdot 10$ & $0 \cdot 20 \pm 0 \cdot 02$ \\
$(\mu \mathrm{mo} / \mathrm{l})$ & $\mathrm{N}$ & $0 \cdot 11 \pm 0 \cdot 03$ & $0 \cdot 52 \pm 0 \cdot 17$ & $0 \cdot 14 \pm 0 \cdot 04$ \\
\hline
\end{tabular}

*Significant diurnal variations: total bacteria in Polya gastrectomy $(p<0.05)$ and in matched control $(p<0.02): \mathrm{No}_{3}$ reducers in matched control $(p<0.05)$ and total NNO in pernicious anaemia $(\mathrm{p}<0 \cdot 025)$. profiles displayed wide variations in the measured parameters. Calculation of mean values for all the gastric juice factors for each subject revealed the same positive relationships between $\mathrm{pH}$ and bacterial counts $(\tau=0.32 ; \mathrm{p}<0.05)$ and nitrite concentration $(\tau=0.40 ; p<0.01)$ and the same negative relationships between $\mathrm{pH}$ and both total $(\tau=-0.40$; $\mathrm{p}<0.01)$ and stable $(\tau=-0.56 ; \mathrm{p}<0.001) \mathrm{N}$-nitroso compounds as revealed by pooling samples according to $\mathrm{pH}$.

\section{GASTRIC JUICE IN POLYA GASTRECTOMY IN PERNICIOUS ANAEMIA AND IN MATCHED CONTROLS}

Mean values from individual subjects were averaged to give values for each diagnostic group. When the daytime data (1000-2130 h; period of feeding and ambulation) were compared with the night time data (2200-0930 h; period of fasting and sleeping) few diurnal variations were revealed (Table 2). In the Polya gastrectomy and the control groups there was a trend towards lower $\mathrm{pH}$ and lower bacterial counts during the night time whilst the pernicious anaemia $\mathrm{pH}$ and bacterial counts were invariably high throughout the 24 hour period indicating overgrowth. Nitrite tended to be lower at night in Polya gastrectomy and pernicious anaemia, and $\mathrm{N}$-nitroso compound concentration in all three groups. Gastric juice factors were compared in Polya gastrectomy, in pernicious anaemia and in matched control (Table 3).

The incidence of counts of bacteria $>10^{5} \mathrm{ml}$ were significantly higher in pernicious anaemia than in matched control (total and nitrate reducing organisms) and Polya gastrectomy (nitrate reducing organisms only; $p<0.025$ ). Although nitrite concentration was higher in pernicious anaemia than in Polya gastrectomy and matched control, only the difference between pernicious anaemia and Polya gastrectomy was significant $(p<0 \cdot 001)$. Both total and stable $\mathrm{N}$-nitrosu compound concentrations were reduced in Polya gastrectomy and pernicious anaemia compared with matched control, but only the differences in stable compounds were significant.

Table 3 Gastric juice in Polya gastrectomy, pernicious anaemia and matched control group.

\begin{tabular}{|c|c|c|c|c|c|}
\hline Factor (mean $\pm S E M)$ & $\begin{array}{l}\text { Polya } \\
\text { gastrectomy }\end{array}$ & $p$ value & Matched control & $p$ value & $\begin{array}{l}\text { Pernicious } \\
\text { anaemia }\end{array}$ \\
\hline $\begin{array}{l}\left.\text { Bacteria (\% samples }>10^{5} \text { org } / \mathrm{ml}\right) \text { : } \\
\text { (a) total } \\
\text { (b) nitrate-reducing } \\
\text { Nitrite }(\mu \mathrm{mol} /) \text { : } \\
\mathrm{N} \text {-nitroso (a) total } \\
(\mu \mathrm{mol} / \mathrm{l})(\mathrm{b}) \text { stable }\end{array}$ & $\begin{array}{c}81 \pm 9 \\
73 \pm 9 \\
10 \cdot 5 \pm 3 \cdot 3 \\
3 \cdot 8 \pm 0 \cdot 6 \\
0 \cdot 19 \pm 0 \cdot 04\end{array}$ & $\begin{array}{l}\text { N.S. } \\
\text { N.S. } \\
\text { N.S. } \\
\text { N.S. } \\
<0.005\end{array}$ & $\begin{array}{c}70 \pm 9 \\
63 \pm 9 \\
26 \cdot 5 \pm 9 \cdot 9 \\
4 \cdot 5 \pm 0 \cdot 5 \\
0 \cdot 57 \pm 0 \cdot 10\end{array}$ & $\begin{array}{l}<0.025 \\
<0.01 \\
\text { N.S. } \\
\text { N.S. } \\
<0.02\end{array}$ & $\begin{array}{l}100 \\
100 \\
57 \cdot 3 \pm 6 \cdot 1 \\
3 \cdot 7 \pm 0 \cdot 5 \\
0 \cdot 18 \pm 0 \cdot 02\end{array}$ \\
\hline
\end{tabular}




\section{GASTRIC ACIDITY}

Differences in gastric juice factors between the two hypochlorhydric conditions and the matched controls were not clear because Polya gastrectomy and matched control groups were heterogeneous for gastric acidity. In individual subjects, intragastric $\mathrm{pH}$ was assessed in terms of the percentage number of samples of $\mathrm{pH}>4$, as bacterial counts were invariably $>10^{5} / \mathrm{ml}$ above this value, suggesting colonisation. Daytime samples were considered independently of night time samples, because otherwise the daytime food intake coupled with a doubled sampling frequency biased the assessments in favour of high $\mathrm{pH}$.

Uniformly high intragastric $\mathrm{pH}$ was displayed by all the pernicious anaemia subjects, and by five of nine Polya gastrectomy and two of nine control subjects (Fig. 5). The intragastric $\mathrm{pH}$ profiles of the remaining subjects (four of nine Polya gastrectomy and seven of nine controls) showed marked fluctuations across the range $\mathrm{pH} 1 \cdot 15-7 \cdot 92$, with a tendency (NS) for high $\mathrm{pH}$ to occur more often during the daytime particularly in the acid secreting Polya gastrectomy subjects. According to our definition of hypoacidity (see Methods) 15 individuals were hypoacidic and 11 were acidic. When assessed in terms of mean $\mathrm{pH}$, these two groups separated into two distinct populations, the acidic group having a mean $\mathrm{pH}$ of $1.72-2.94$ and the hypoacidic group having a mean $\mathrm{pH}$ of 4.07-6.03. No subjects had a mean pH between 3 and 4 .

\section{GASTRIC JUICE IN HYPOACIDIC AND ACIDIC} GROUPS

There were significant diurnal variations in bacterial counts (total and nitrate reducing) in the acidic group, with higher counts occurring during the daytime (Table 4). In addition there were trends

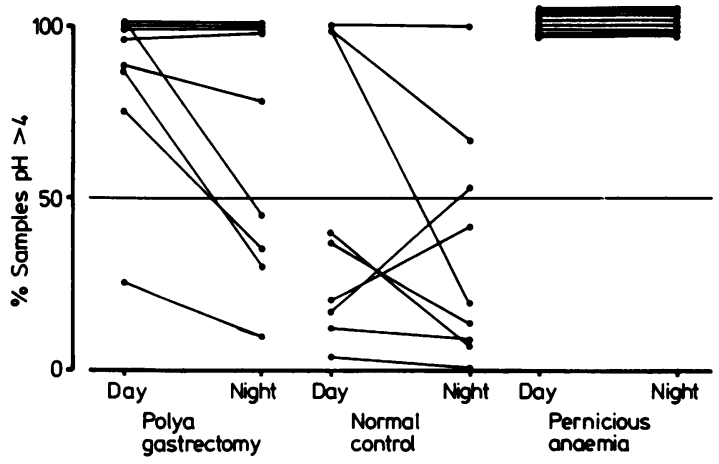

Fig. 5 Incidence of hypoacidity in disease groups (hypoacidity defined as intragastric $\mathrm{pH}>4>50 \%$ of both daytime and night time samples).
Table 4 Diurnal variations and gastric acidity

\begin{tabular}{|c|c|c|c|}
\hline Factor $( \pm S E M)$ & $\begin{array}{l}\text { Day/ } \\
\text { night }\end{array}$ & Acidic & Hypoacidic \\
\hline $\begin{array}{l}\text { pH } \\
\quad(\% \text { samples }>\mathrm{pH} 4)\end{array}$ & $\begin{array}{l}\mathrm{D} \\
\mathrm{N}\end{array}$ & $\begin{array}{l}46 \cdot 3 \pm 11 \\
24 \cdot 4 \pm 5\end{array}$ & $\begin{array}{l}98 \cdot 9 \pm 1 \\
96 \cdot 4 \pm 1\end{array}$ \\
\hline Total bacteria & D & $81 \cdot 0 \pm 6^{*}$ & 100 \\
\hline (\% samples $>10^{5} \mathrm{org} / \mathrm{ml}$ ) & $\mathbf{N}$ & $38 \cdot 8 \pm 10$ & 100 \\
\hline $\begin{array}{l}\mathrm{No}_{3} \text { reducers } \\
\left(\% \text { samples }>10^{5} \text { org } / \mathrm{ml}\right)\end{array}$ & $\begin{array}{l}\mathrm{D} \\
\mathrm{N}\end{array}$ & $\begin{array}{l}70 \cdot 8 \pm 6^{*} \\
34 \cdot 2 \pm 9\end{array}$ & $\begin{array}{l}97 \cdot 2 \pm 2 \\
97 \cdot 2 \pm 2\end{array}$ \\
\hline Nitrite & $\mathrm{D}$ & $12 \cdot 7 \pm 5$ & $45 \cdot 5 \pm 7$ \\
\hline$(\mu \mathrm{mol} / \mathrm{l})$ & $\mathbf{N}$ & $7 \cdot 7 \pm 5$ & $39 \cdot 6 \pm 9$ \\
\hline $\begin{array}{l}\text { Total N-nitroso } \\
(\mu \mathrm{mol} / \mathrm{l})\end{array}$ & $\begin{array}{l}\mathrm{D} \\
\mathrm{N}\end{array}$ & $\begin{array}{l}5 \cdot 0 \pm 0 \cdot 4 \\
4 \cdot 3 \pm 0 \cdot 6\end{array}$ & $\begin{array}{l}3 \cdot 8 \pm 0 \cdot 5 \\
2 \cdot 6 \pm 0 \cdot 3\end{array}$ \\
\hline Stable N-nitroso & D & $0 \cdot 57 \pm 0 \cdot 10$ & $0 \cdot 19 \pm 0 \cdot 02$ \\
\hline$(\mu \mathrm{mol} / \mathrm{l})$ & $\mathrm{N}$ & $0 \cdot 42 \pm 0 \cdot 15$ & $0 \cdot 13 \pm 0 \cdot 04$ \\
\hline
\end{tabular}

*Significant diurnal variations: in total $(\mathrm{p}<0.001)$ and in $\mathrm{No}_{3}$ reducing $(p<0.001)$ organisms in the acidic subjects only.

Table 5 Gastric juice in hypoacidic and acidic groups

\begin{tabular}{lccl}
\hline Factor (mean \pm SEM) & Acidic & Hypoacidic & $p$ value \\
\hline Bacteria (\% samples & & & \\
$\quad>10^{5}$ org/ml): & & & \\
(a) total & $60 \pm 7$ & $100 \%$ & $<0.01$ \\
(b) nitrate-reducing & $53 \pm 7$ & $96 \pm 2$ & $<0.01$ \\
Nitrite $(\mu \mathrm{mol} / \mathrm{l})$ & $11.9 \pm 5.0$ & $44.0 \pm 7.0$ & $<0.01$ \\
N-nitroso (a) total & $4.8 \pm 0.3$ & $3.4 \pm 0.4$ & $\mathrm{NS}$ \\
( $\mu$ mol/l) (b) stable & $0.52 \pm 0.09$ & $0.17 \pm 0.02$ & $\mathrm{NS}$ \\
\hline
\end{tabular}

towards lower $\mathrm{pH}$ and lower concentrations of nitrite and $\mathrm{N}$-nitroso compounds during the night. In the hypoacidic group, $\mathrm{pH}$ and bacterial counts were invariably high throughout the 24 hour period indicating overgrowth. Again nitrite and $\mathrm{N}$-nitroso compound concentrations tended to be lower during the night. Bacterial counts and nitrite concentrations were significantly higher and $\mathrm{N}$-nitroso compound concentrations tended to be lower in the hypoacidic group compared with the acidic group (Table 5).

\section{Discussion}

Gastric juice analysis is most commonly done on single samples of fasting gastric juice aspirated at endoscopy. This practice has the advantage that multiple investigations, such as gastric inspection, biopsy, and juice sampling, may be accomplished at the same time with minimal disturbance to the patient, but gastric juice collected in this manner may be impure and may not be fully representative of the gastric content under normal conditions. The passage of any gastric tube may stimulate unnatural bile reflux and this is likely to be maximal at endoscopy because of the large size of the instru- 
ment, the administration of a sedative and the head down positioning of the patient. Such artifactual bile reflux may lead to inaccuracies in gastric juice analysis, particularly in the Polya gastrectomy stomach where stomal incompetence compounds the stimulus of endoscopy, and where contamination may have greatest influence because of the reduced volume of gastric secretion. For instance, bile reflux may result in an inaccurately high estimation of intragastric $\mathrm{pH}$ as a result of neutralising gastric acid.

We aimed to minimise gastric tube artifacts by using the smallest effective nasogastric tube; by siting the tube accurately and checking its position at the end of the study; and by delaying aspiration for one hour after tube siting to allow a steady state to develop. By taking these precautions and by assessing intragastric $\mathrm{pH}$ for a prolonged period, designed to simulate normal daily life, we recorded a mean 24 hour $\mathrm{pH}$ value of 2.9 in our Polya gastrectomy group. By contrast, studies ${ }^{22}{ }^{23}$ involving endoscopic aspiration of single samples of fasting gastric juice have given a much higher mean $\mathrm{pH}$ value for Polya gastrectomy ( $\mathrm{pH} 6 \cdot 5-7 \cdot 3)$, possibly because of artefactual bile reflux. Furthermore, as the composition of gastric juice varied. widely over the 24 hour period, including the overnight fast, it is apparent that gastric juice analysis in single fasting samples is of limited value. We expressed mean $\mathrm{pH}$ as the arithmetical mean of a logarithmic function, a standard statistical approach to handling data. The mean was calculated for comparison between groups, rather than for the interest of the absolute values, and mean is the most informative statistic.

Many studies ${ }^{24-26}$ including this one have shown a positive correlation between intragastric $\mathrm{pH}$ and both bacterial count and nitrite concentration, supporting the first steps in the nitrosamine hypothesis of gastric carcinogenesis. By contrast, we found a negative correlation between intragastric $\mathrm{pH}$ and $\mathrm{N}$-nitroso compound concentration, suggesting that the chemical mechanism of nitrosation predominates in the human stomach. We measured total $\mathrm{N}$-nitroso compounds at the bedside immediately upon the aspiration of gastric juice, because storage of sample before analysis may promote the artifactual synthesis and degradation of $\mathrm{N}$-nitroso compounds in vitro. ${ }^{27}$ Keighley and colleagues ${ }^{28}$ have used the same methodology as in the present report to study patients who had had a variety of gastric operations for duodenal ulcer. They did not study Polya gastrectomy, which we studied specifically because it is the gastric operation which has been most convincingly demonstrated to represent a precancerous condition, ${ }^{29}{ }^{30}$ nor did they study pernicious anaemia. Their findings differ from ours in failing to show a correlation between $\mathrm{N}$-nitroso compounds and $\mathrm{pH}$, possibly because their statistical methods were different. Our findings are in actual contradiction to those of Reed and colleagues $^{25}$ who investigated total $\mathrm{N}$-nitroso compounds in the fasting gastric juice of subjects suffering from a variety of gastric disorders including Polya gastrectomy and pernicious anaemia, and found a positive correlation beween intragastric $\mathrm{pH}$ and $\mathrm{N}$-nitroso compound concentration. They measured total N-nitroso compounds by the method of Walters $e^{2} a^{31}$ which involves the storage of sample before analysis. Bartsch et al ${ }^{32}$ also used the method of Walters et al and they found no relationship between intragastric $\mathrm{pH}$ and total gastric $\mathrm{N}$-nitroso compound concentration. In the same study, however, they also investigated nitrosation from the urinary excretion of $\mathrm{N}$-nitrosoproline, (believed to be synthesised intragastrically) and reported maximal yields of this compound at intragastric $\mathrm{pH} 2 \cdot 0-2 \cdot 5$. This latter finding is in keeping with our own, and provides further evidence that intragastric nitrosation is largely a chemical process not involving bacteria.

Analysis of gastric juice in individuals and in groups of subjects revealed non-significant trends towards higher values during the daytime for $\mathrm{pH}$ (in acid secreting subjects only), bacterial counts, nitrite and $\mathrm{N}$-nitroso compound concentrations. It is probable that daytime feeding increased the availability of precursors of nitrosation, but at the same time neutralised gastric acidity and therefore limited $\mathrm{N}$-nitroso compound synthesis to levels not much higher than at night time. Furthermore, daytime nitrite and $\mathrm{N}$-nitroso compound concentrations may have been reduced by the dilutional effect of food. Like food, bile reflux may have influenced our results, and a full account of the biliary and pancreatic factors in our samples is to be presented separately. As reported already in a preliminary communication, ${ }^{33}$ total bile acid concentration was much higher in Polya gastrectomy than in pernicious anaemia and matched control; in addition nocturnal bile acid concentration in Polya gastrectomy was significantly greater than daytime concentration. As bacteria, nitrite and $\mathrm{N}$-nitroso compounds were all related to intragastric $\mathrm{pH}$, bile reflux may have influenced these factors in Polya gastrectomy by neutralising acid and raising $\mathrm{pH}$. Four of nine Polya gastrectomy, however, displayed a profound fall in intragastric $\mathrm{pH}$ during the night when bile reflux was maximal, which suggests that the neutralising capacity of bile reflux on its own may be small in comparison to the neutralising capacity of daytime food. Standardisation of data for $\mathrm{pH}$ revealed no significant differences in bacterial counts or $\mathrm{N}$ - 
nitroso compound concentrations in Polya gastrectomy compared with matched control and pernicious anaemia, which suggests that bile reflux has no great effect on these factors. On the other hand, whilst nitrite was similarly related to $\mathrm{pH}$ in Polya gastrectomy as in pernicious anaemia and matched control, lower concentrations were recorded in Polya gastrectomy although only the difference between Polya gastrectomy and pernicious anaemia was significant (Table 3 ). This finding suggests that bile reflux influences nitrite metabolism and is consistent with the observation that nitrite added to gastric juice in vitro is consumed in samples contaminated with bile (Dr B C Challis, personal communication).

Clear cut differences in gastric juice were lacking between the matched control group and the hypochlorhydric pernicious anaemia and Polya gastrectomy groups, because matched control and Polya gastrectomy groups were heterogeneous for gastric acidity. The $22 \%$ (two of nine) incidence of hypoacidity (and therefore hypochlorhydria) in the matched control group corresponds with the reported $18-35 \%$ idiopathic hypochlorhydria in older populations. ${ }^{134}{ }^{35}$ Rearrangement of subjects into hypoacidic and acidic groups revealed bacterial overgrowth, higher nitrite concentrations, and a tendency for lower $\mathrm{N}$-nitroso compound concentrations in the hypoacidic group.

We have recently shown ${ }^{36}$ that gastric surgery is associated with an increased incidence of cancer of not only the stomach, but also of other organs - for example, colon, biliary tract, bronchus etc, after a 15-20 year latency period. This finding is consistent with the hypothesis that bacteria in the hypoacidic stomach, after gastric surgery, generate circulating carcinogens. The findings in the present study suggests that these carcinogens are not $\mathrm{N}$-nitroso compounds. Alternatively, $\mathrm{N}$-nitroso compounds in reduced quantitites may be carcinogenic in the hypoacidic stomach. The mucous barrier which protects the normal stomach from autodigestion may also prevent $\mathrm{N}$-nitroso compounds from penetrating the gastric cells. Deficiencies in this barrier may facilitate the access of $\mathrm{N}$-nitroso compounds to the gastric cells, and other factors such as increased cell turnover and reduced DNA repair enzymes ${ }^{37}$ may promote the carcinogenicity of $\mathrm{N}$-nitroso compounds in the hypoacidic stomach.

We are grateful to Dr Martin Bland, $\mathrm{PhD}$ for professional statistical advice, and to British Petroleum Co Ltd, and Shell UK Ltd for financial assistance.

\section{References}

1 Hebbel R. The topography of chronic gastritis in cancer-bearing stomachs. J Natl Cancer Inst 1949; 10: 505-22.

2 Hitchcock DR, Scheiner SL. Early diagnosis of gastric cancer. Surg Gynecol Obstet 1961; 113: 665-72.

3 Comfort MW, Kelsey MP, Berkson J. Gastric acidity before and after the development of carcinoma of the stomach. J Natl Cancer Inst 1946-47; 7: 367-73.

4 Stalsberg H, Taksdal S. Stomach cancer following gastric surgery for benign conditions. Lancet 1971; 2: $1175-7$.

5 Lygidakis NJ. Gastric stump carcinoma after surgery for gastroduodenal ulcer. Ann R Col Surg Edinb 1981; 63: 203-5.

6 Orlando R, Welch JP. Carcinoma of the stomach after gastric operation. Am J Surg 1981; 141: 487-91.

7 Blackburn EK, Callender ST, Dacie JV et al. Possible association between pernicious anaemia and leukaemia: A prospective study of 1,625 patients with a note on the very high incidence of stomach cancer. Int $J$ Cancer 1968; 3: 163-70.

8 Elsborg L, Mosbech J. Pernicious anaemia as a risk factor in gastric cancer. Acta Med Scand 1979; 206: 315-8.

9 Morson BC, Sobin LH, Grundmann E, Johansen A, Nagayo T, Serck-Hanssen A. Precancerous conditions and epithelial dysplasia in the stomach. J Clin Pathol 1980; 33: 711-21.

10 Correa P, Haenszel W, Cuello C, Tannenbaum S, Archer M. A model for gastric cancer epidemiology. Lancet 1975; 2: 58-60.

11 Ruddell WSJ, Bone ES, Hill MJ, Walters CL. Pathogenesis of gastric cancer in pernicious anaemia. Lancet 1978; 1: 521-3.

12 Lijinsky W. Current concepts in the toxicology of nitrates, nitrites and nitrosamines. In: Mehlman MA, Shapiro RE, Blumenthal H, eds. Advances in modern toxicology, Vol. 1: Sussex and New York: Wiley, 1979: $149-64$.

13 Douglass ML, Kabacoff BL, Anderson GA, Cheng $\mathrm{MC}$. The chemistry of nitrosamine formation, inhibition and destruction. J Soc Cosmet Chem 1978; 29: 581-606.

14 Hawksworth GM, Hill MJ. Bacteria and the nitrosation of secondary amines. Br J Cancer 1971; 25: 520-6.

15 Mills AL, Alexander M. N-nitrosamine formation by cultures of several microorganisms. Appl Environ Microbiol 1976; 31: 892-5.

16 Ayanaba A, Alexander M. Microbial formation of nitrosamines in vitro. Appl Microbiol 1973; 25: 862-8.

17 Ralt D, Tannenbaum SR. The role of bacteria in nitrosamine formation. In: $N$-nitroso compounds. ACS Symposium Series 174. Washington DC: ACS, 1981.

18 Borriello P, Hudson M, Hill MJ. Investigation of the gastrointestinal bacterial flora. Clin Gastroenterol 1978; 7: 329-49.

19 Drasar BS, Hill MJ. In: Human intestinal flora. London: Academic Press, 1974.

20 Bavin PMG, Darkin DW, Viney NJ. Total nitroso compounds in gastric juice. In: $N$-nitroso compounds: 
occurrence and biological effects. IARC Publ. no. 41, Lyon: IARC, 1982: 337-44.

21 Armitage P. Methods in medical research. Oxford: Blackwell Press, 1971: 203-4, and 363-5.

22 Schlag P, Bockler R, Ulrich H, Peter M, Merkle P, Herfarth $\mathrm{CH}$. Are nitrite and $\mathrm{N}$-nitroso compounds in gastric juice risk factors for carcinoma in the operated stomach? Lancet 1980; 1: 727-9.

23 Domellof L, Reddy SS, Weisburger JH. Microflora and deconjugation of bile acids in alkaline reflux after partial gastrectomy. Am J Surg 1980; 140: 291-5.

24 Ruddell WSJ, Bone ES, Hill MJ, Blendis LM, Walters CL. Gastric-juice nitrite. A risk factor for cancer of the hypochlorhydric stomach. Lancet 1976; 2: 1037-9.

25 Reed PI, Smith PLR, Haines K, House FR, Walters $\mathrm{CL}$. Gastric juice N-nitrosamines in health and gastroduodenal disease. Lancet 1981; 2: 550-2.

26 Schlag P, Bockler R, Peter M, Herfarth $\mathrm{CH}$. Nitrite and $\mathrm{N}$-nistroso compounds in the operated stomach. Scand J Gastroenterol 1981; 16: suppl 67: 63-9.

27 Ruddell WSJ, Walters CL. Nitrite and N-nitroso compounds in gastric juice. Lancet 1980; 1: 1187.

28 Keighley MRB, Youngs D, Poxom V, et al. Intragastric $\mathrm{N}$-nitrosation is unlikely to be responsible for gastric carcinoma developing after operations for duodenal ulcer. Gut 1984; 25: 238-45.

29 Domellof L, Eriksson S, Janunger KG. Carcinoma and possible precancerous changes of the gastric stump after Billroth II resection. Gastroenterology 1977; 73: 462-8.
30 Schrumps E, Staduas J, Myren J, Serck-Hanssen A, Aumes S, Osnes M. Mucosal changes in the gastric stump 20-25 years after partial gastrectomy. Lancet 1977; 2: 467-9.

31 Walters CL, Downes MJ, Edwards MW, Smith PLR. Determination of a non-volatile $\mathrm{N}$-nitrosamine on a food matrix. Analyst 1978; 103: 1127-33.

32 Bartsch $\mathrm{H}$, Oshima $\mathrm{H}$, Munoz $\mathrm{N}$, et al. In vivo nitrosation, precancerous lesions and cancers of the gastrointestinal tract: ongoing studies and preliminary results. Lyon: IARC, 1984, no. 57.

33 Hall CN, Viney N, Kirkham JS, Northfield TC. Diurnal variation in bile acid reflux in Polya gastrectomy patients. [Abstract]. Gut 1983; 24: A477.

34 Polland WS. Histamine test meals, an analysis of nine hundred and eighty eight consecutive tests. Arch Intern Med 1933; 51: 903-19.

35 Christiansen PM. The incidence of achlorhydria and hypochlorhydria in healthy subjects and patients with gastrointestinal disease. Scand J Gastroenterol 1968; 3: 497-508.

36 Caygill CPJ, Hill MJ, Hall CN, Kirkham JS, Northfield TC. Gastric surgery as a risk factor in human carcinogenesis. [Abstract]. Gut 1985; 26: A563.

37 Pegg AE. Properties of the $\mathrm{O}^{6}$-alkylguanine-DNA repair system of mammalian cells. In: O'Neill IK, Miller CT, von Borstel RC, Long JE, Bartsch $\mathrm{H}$, eds. $N$-nitroso compounds: occurrence, biological effects and relevance to human cancer. Lyon: IARC: 1984, no. 57. 